\title{
THE RELATIONSHIP BETWEEN THE DEVELOPMENT OF THE HIGHER EDUCATION IN ROMANIA AND THE ACCOUNTING PROFESSION
}

\author{
Teodora Viorica Fărcaş ${ }^{1}$ \\ Adriana Tiron Tudor ${ }^{2}$
}

ABSTRACT: This paper wants to highlights the relation between the development of accounting in Romania and the accounting profession. The development of the accounting education is related with the economical development as well as the profession. Having intellectuals that are preoccupied of accounting we will have the need of having a recognized group. The Body of Charted Accountants was correlated with the appearance of the second Academy of Industrial Studies in Romania and only after the Unification.

We could see that the ones that initiate the organization of the accounting profession in Romania were the Alumni of the Commercial Schools.

Key words: schools of commerce, accounting profession, Academy, alumni

JEL Codes: $B 25$

\section{Introduction}

The problem of professionalization in accounting is a much debated subject nowadays at an international level. Most of the accounting history specialist from Anglo-Saxons territories, and not only, are trying to find the relationship between the accounting profession and the evolution of the education.

Late XIX and early XX century is the crystallization of capitalist relations in Romania, Transylvania in those time was not part of Romania. Structuring state institutions and the development of the companies requires the organization of the accounting system at the enterprise level and government level. Because of the lack of a legal framework that deals with keeping of records and accounting data recording and processing were held in most cases, by unqualified people. The need to appoint competent persons to deal with legal expertise made to speed up the crystallization and organization of the accounting profession.

The objective of our paper is to show the relations between the accounting profession and the development of the education in the accounting field in Romania, and going a little deeper in Transylvania. Also we want to demonstrate the contribution of the higher education in the professionalization process in Romania.

The accounting education started in her incipient form in XIX century in Romanian territories. The evolution of the economy required the appearance of education forms in the commerce field and did not developed unitary on the territory of Romania.

The accounting education started in our country as bookkeeping trained in the schools of commerce, ,which were specialized institutions for professional business education”.(Zelinschi, 2006). The first schools of commerce appeared in Bucharest and Giurgiu in 1864, this towns being part of Romania. In Transylvania a school of commerce appeared in 1868 in Brasov and was the only one in Romanian language from this Romanian territory.

\footnotetext{
1 Babes-Bolyai University, Faculty of Economics and Business Administration, e-mail: teodora.farcas@econ.ubbcluj.ro

${ }^{2}$ Babes-Bolyai University, Faculty of Economics and Business Administration, e-mail: adriana.tiron@econ.ubbcluj.ro
} 
In 1913, in Bucharest, it is formed the first form of Higher Education in the economic field from Romania, the Academy of High Commercial and Industrial Studies from Bucharest. After the Great Union, when Transylvania became part of Romania, in 1920, in Cluj is developed the second Academy of High Commercial and Industrial Studies, being the first institution of higher education in the economic and accounting field from Transylvania in the Romanian language.

The year 1920, is also the year when the Body of Charted Accountants is being formed. This was the first body of the accounting profession legalized by a law and recognized at national and international level.

Our article will be divided into three major sections. Firstly we will present the methodology and theoretical framework. Secondly we are presenting the literature used for sustaining our article and in the third part it will be the core of the article, in which we will present the evolution of the accounting education in relation with the development of the accounting profession.

\section{Methodological approaches}

We will conduct a qualitative study of the history of accounting profession and education. It will be a contextual analysis with the intention to elucidate the evolution of education in the accounting field and the evolution of the profesion in Romania, by presenting events as they happend, with the scope of capturing the everyday behaviour.

We founded our research on the model of historical works on accounting bodies used by Brown (1905), Garrett (1961), Institute of Chartered Accountants of Scotland (1954), Institute of Chartered Accountants in England and Wales (1966) and Carey (1969) as examples of works which had been written "from the inside".

From a methodological point of view, it was conducted a thorough study of relevant (mainly Romanian) literature available (textual analysis). We have studied primary and secondary data of information about the Romania history, accounting education in Romania, and about the Academy of High Commercial and Industrial Studies in order to become familiarized with the process of accounting education and accounting profesionalization through time.

We have tryed to fundament our paper on Abbott's theory which explains the relationship between the higher education forms and the profession. Due to this theory we will support our objective of proving the strong influence of the development of higher education and the accounting profession.

Abbott (1988) defines academic knowledge as the ,formal ordering of professional knowledge" (Abbott, 1988, p.54). The knowledge given by the school in the system of professions has three roles: it legalizes the profession by giving it cultural values (e.g. rationality, logic, science), through research it develops new ways of treating and diagnosing the problems of professional practice, and it provides instruction.

Academics, as the counterpart to practitioners, play a critical role. As Abbott says: "Academic professionals demonstrate the rigor, the clarity, and the scientifically logical character of professional work, thereby legitimating that work in the context of larger values" (1988, p.54).

\section{Literature review}

The literature for the accounting history in Romania is not too much. We have few authors that wrote about accounting history and economic history. Also we have the authors that wrote the history of the Academy from Bucharest and from Cluj.

At international level the accounting education and accounting profesion are subjects that interested and still interest many authors.

Nationally there have been several authors such as: Demetrescu, CG (1930), Pop D. (2005), Calu, D., A. (2005), Tiron Tudor, A. and Matis, D. (2010), Popescu, Gh. (2010), Vorovenci, I. (2010), Zelinschi D. (2009) which covered topics relating to international accounting history including Romania. 
C.G. Demetrescu (1930) wrote the book "The History of the Accountancy", in which presents the development of the accountancy at international level from the beginnings till the second half of the $20^{\text {th }}$ century. It also includes the history of Romanian territories.

D.A. Calu wrote "The history and development in the accountancy field in Romania", wich is one of the few books about accounting history in Romania and brings lots of important elements.

The work of D. Pop is important in the economic history because it presents the economic school from Cluj-Napoca, being focused on the Academy of High Commercial and Industrial Studies.

A.Tiron Tudor and D. Matis had an interest in the accounting history in Transylvania. They wrote an article about the economic situation of Transylvania in the $19^{\text {th }}$ centry.

G. Popescu coordinated the writing of the book about the history of the Faculty of Economics and Business Administration, Cluj-Napoca. This history includes also the presentation of the object of our paper, the first schools of accounting.

I.Vorovenci is the author that wrote the history of the Academy of High Commercial and Industrial Studies from Bucharest. In his book he is developing the evolution of the economic education in Romania.

D. Zelinschi, is a young author, who has developed a valuable article about the accounting profession in Romania, its contribution in the field of accounting history in our country is very high, given that published this article in Accounting History Review. His article, ,Legitimacy, expertise and closure in the Romanian Accountants' Professional Project, 1900-1916”, helped us a lot whit the idea of professionalization in Romania.

There were international authors like Walker (2009), Carnegie and Napier (2011), West (2003), Dyball, Chua and Poullaos (1993), which wrote about accounting profession, professionalization of the accounting. This literature helped us to conduct our study in the area of professionalization.

Walker, is one of the leading authors in the field of accounting history, being the editor of Accounting History. This along with Anderson-Goughin and Edwards wrote a very interesting paper on the accounting education link with accounting profession The authors discuss in „The Routledge Companion to Accounting History" (2009), the influence of education and the profession, one on each other, and the importance of education in shaping the accounting profession.

Carnegie and Napier (1996), these two great teachers of accounting history, wrote many works on the professionalisation of accounting and accounting education in the UK and Australia. The work we studied is actually a literature review that the authors want to make a trip through time and see the style that is used today in writing historical accounts. „Critical and interpretive Histories: Insights into accounting's present and future through its Past" is the article that wants to show the current trend in dealing with history books, the authors concluding that there are two types of trends: one focused on the discovery of history in terms of theories social, contextual, and another study based on archives. Our paper is combining the two of them.

Along with Carnegie wrote also West and Edwards in 2003 with a study of the accounting profession in Australia. They come with a new concept prosopografica method by which the study carried out by wanting to see the connection between the key figures who founded the Australian Corporation of Public Accountants and the accounting profession.

Dyball,Chua and Poullaos (1993) have written an article about the development of accounting profession in the Philippines given that this country was under U.S. domination. They debate the issue of the accounting profession as a reaction of resistance to domination. 


\section{Academy}

The development of accounting education from the Schools of Commerce till the

Before XIX century there was no need for financial statements because the businesses were not big and most owners had direct knowledge of their own bussines, therefore they could rely only on bookkeeping for informations.

Althought there were proofs that forms of accounting were used in the Romanian territories long before, considering the registers and accounting books found for several very old estates of the time, but a significant development was only visible starting the second half of the XVIII century, when commerce began developing.

As a consequence to the development of the industry and business more and more knowledge of accounting were needed. Elementary accounting knowledge was taught in the schools of commerce.

\section{The schools of commerce}

Romania was a country that most of the time till the XIX century had to fight against others to maintain its independence. As a consequence of this situation the commerce in Romania was not so developed, only after 1877 , when the country obtained its independence, the commerce with cereals begins to developed.

So, in XIX century the economic development requests qualified employees in industrial, agricultural and trade activities. For this reason some of the leaders of the territories that today are all together Romania, wanted to introduce in schools the study of commerce, in 1850 and 1853. (Vorovenci, 2010). In towns like Iasi, Braila, Galati the commerce was taught in the elementary schools, and in Ploiesti, in 1859-1860, there was a class of commerce.(Idieru, 1907) The first two schools of commerce were created in Bucharest and Galați in 1864.

On the other hand, in Transylvania, the Trade and Industry Chambers (founded by law in 1850) supported the foundation of commercial schools for trade and other business activities.

In Transylvania were 14 commercial schools with a three years study curricula including discipline like: trade history, accounting, business correspondence, commercial mathematics, economics principles, and commercial law. In parallel, there were some projects concerning the foundation of higher studies in economics.

In 1835, in Cluj was founded the Normal Trade School and in the second part of XIX century was founded the High School of Trade and in 1902, at the Trade and Industry Chamber of Cluj, was founded the Trade Academy of Cluj. The two years curricula of the Academy consist theoretical and practical knowledge combined with economic legal framework. The management, the pedagogical activities and the curricula were influenced by that time models from Vienna, Budapest, Prague and Bratislava, but taking into consideration the Transylvanian economies needs.

In 1868 it was built the school of commerce in Transylvania, in Brasov (the only one in Romanian language from this territory).

In 1864 trough the Law of public instruction, it is regulated the teaching in the commercial schools. The courses that were taught in these schools were: commercial and maritime law, accountancy, commercial geography, commercial correspondence, political economy and administrative law.

At the beginning the elementary schools were courses lasted four years and commercial schools five years. The commercial schools were divided into two categories: schools with the degree I and schools with the degree II. At the commercial schools with the second degree could assist the candidates from the elementary schools and also from the commercial schools with the first degree.

There were also two other laws, in 1893 and 1899, that were regulating the professional education and supported the commercial courses. 
After a while it was noticed that only few students were finishing the school and this is why the period of the courses was reduced to three years for the elementary schools of commerce and at four years for the high schools of commerce. ,The courses taught in the schools of commerce were primarily practical and accounting was concerning only the facts of commerce. The graduates enjoyed good career opportunities, especially in accountancy, banking, education and public administration. They predominantly filled positions as accountants in the private or public sectors." (Zelinschi, 2006)

So, even if the schools of commerce weren't the best schools and only a little part of the population wanted to attend these courses, they were the fundament for the creation of the accounting profession, which was elementary for the development of the national economy.

In our opinion the educational institutions (schools of commerce) which develop, transfer and legalize the body of knowledge, are an important part of the accounting history in any country. The schools had also the role of establishing a social network and a community which shares the same formal education and professional interests in the early XIX century. ,,The schools of commerce in Romania were the primary institutions which diffused accounting knowledge, in addition, the alumni of these schools formed a well developed network that provided a basis for building the accounting profession." (Zelinschi, 2006).

\section{The Academy of High Commercial and Industrial Studies from Bucharest and Cluj}

As Professor Walker says in his work, the national contexts set the conditions for the development of accounting in universities (Anderson-Goughin, Edwards and Walker, 2009) So it was in Romania, after the development of the schools of commerce and the Superior schools of commerce, there was felt the need of having higher education in the economic field too.

In 1913, after several discussions of the well educated younger from Romania, with the Minister of Industry and Commerce, about the need of having higher education in the economic field in our country, they succeeded to have the law of the set up of the Academy of High Commercial and Industrial Studies. The Academy was set up in Bucharest and was the first real form of higher education in the economic field from Romania. This Academy was structured like the ones in Germany, France and Belgium (Pop, D., 2005).

The ideas for the organisation of the Academy came from the alumni of the schools of commerce which were grouped since 1888 in an association, "the Circle of the Alumni of the Schools of Commerce and Finance of Romania and Overseas" (Cercul Absolvenților Şcolilor Comerciale şi Financiare din Țară şi Străinătate). They were the elite group from Romania and they will fight for the development of the accounting profesion, too.

The courses at the Academy were lasting three years and it could attend the ones that finished the classes of the schools of commerce and the ones from the secondary and superior schools.

The Academy was structured into 3 sections:

- commerce, bank, assurance

- industry

- economical and consular administration

This Academy had an important role for the development of the secondary education, preparing future professors for the secondary education. It also provided an important platform for the practitioners, because there were summer courses for them.

The second Academy of High Commercial and Industrial Studies established in ClujNapoca in 1920. The institution was structured in two groups of sections:

- Commerce, Bank, Insurance Section

- Industrial Section

After a while there was a re-structuring of the sections in three groups of specialization:

- Economic Sciences 
- Financial Sciences

- Social Sciences

Based on the above, it can be noticed that at the Academy was no Accountancy section, in spite of this in the university environment, it is very important to understand the relationship of the accountancy with economics and also the accounting itself through educational practices. However, accounting itself was to become increasingly distanced from a very theoretical mathematically oriented economics (Sanderson 1972: 202). Solomons (1974) identifies the McNair Report (which instigated the Universities Scheme) as the source of a problematic relationship with economics. In Solomons' view this scheme maintained accounting in a subordinate position within universities.(Anderson Goughin J.R., Edwards and Walker, 2009)

The professores which were teaching accountancy in these two Academies were Alumni from the commercial schools wich had a practice in business at least ten years.

The Academy from Cluj had an interesting history, because in 1940 after Vienna Dicktat, the town of Cluj became part of Hungary, so the Academy with all the professors and students moved to Brasov, other town from Transylvania, and continues his activity here till 1947. For one year till 1948 it functiond in iasi and after that it was abolished by the communism.

\section{The rise of Accounting Profession in Romania}

In 1888, a group of graduates from the schools of commerce, mostly senior officials of the National Bank, established "the Circle of the Alumni of the Schools of Commerce and Finance of Romania and Overseas" (Cercul Absolvenților Şcolilor Comerciale şi Financiare din Țară şi Străinătate), whose president is elected Professor Theodor Stefanescu. The stated goal of the Circle was the "organization and regulation of an association of accountants" (CECCAR, 2011), but also wanted to fight for the rights of the alumni and helping them finding jobs.

In 1898, Graduates Circle turns into Alumni Association of Superior Schools of Commerce, chaired by Theodor Stefanescu and having Mr. Nicolae Butculescu as secretary.

After three years, on 22 April 1901, the most representative graduates of the trade schools across the country gather in the Capital, where in the wards of company Liedertafel, were celebrating the anniversary of 30 years of activity of Professor Theodor Stefanescu and its withdrawal to pension. Here they resume discussions on regulating the accounting profession and the steps that were needed to be taken in this regard. So, in the same year, a memorandum was send to the President of the Chamber of Commerce in Bucharest for regulating the expertise exercice in accounting. Unfortunately, the Chamber of Commerce, didn't make any approach towards the requirements expressed.

In 1906, on October 29, with the occasion of the National Exhibition in the Park Carol I, Professor Spiridon Iacobescu organized the first Congress of the Alumni Association of Superior Schools of Commerce, where the first point of the program appear to be "need for the profession of accounting regulation", especially interrupting the serious error of giving such accounting expertise to persons that were not having any accounting knowledge. (CECCAR, 2011)

From some personal ambitions, there is a split in the middle of this association and, in 1907, some members set up the Alumni Union of Commerce Schools, under the chairmanship of I.Şt. Rasidescu.

In April 1910, the two organizations become one, as the Alumni Body of the Higher Schools of Commerce, having Nicolae Butculescu as president, and Vasile M. Ioachim and Nicolae Arghir as vice presidents. Vasile M. Ioachim was a director at the Peasant Society and Nicolae Arghir was a director at the Ministry of Recovery and Supply. But six years will pass until the Alumni Body will acquire legal personality by the Law of 17 February 1916.

The outbreak of the First World War made the move of the alumni stop between 1914 and 1918 , being resumed only after the war. 
In 1918 is established the Circle of Comercial Studies, and following the call of Nicolae Butculescu, the fight for the establishment the Body of accountants is resumed with greater perseverance.

On 5 May 1919 Circle of Commercial Studies inaugurated its activity in the Palace of the Chamber of Commerce with the conference organized by Peter Draganescu-Brateş on the subject "matter of Chartered Accountants in Romania".

After several discussions on this issue and contradictory, to give a practical and easy way to achive the Body, Vasile M. Ioachim and Petru Draganescu-Brateş drew up a project to organize a Body of accounting experts, which was presented to the Circle of Commercial Studies. Following Butculescu proposal, the project was completed with the regulation of accounting profession in general, too, not just accountants.

In July 1920, the draft was given to Grigore Trancu-Iasi, the Minister of Labour, with the request of being studied. The project was voted by the Chamber of Deputies in the meeting of 18 June 1921, and in the meeting of 1 July 1921 was voted in the Senate.

This completes the first stage of the emancipation movement of professional accountants in Romania. Comes the second stage, the organization and consolidation of the newborn - The body of Chartered Accountants and Experts Accountants.

\section{The Body}

On 29 October 1921, for the second stage of movement of professional accountants in Romania, was the most important day. On this day, in the presence of over 400 members, has taken the first step in applying the Law of the Body, by choosing the first section of the country, Section Ilfov, composed of the following persons, most of them being professores at the Academies: C.D. Staicovici - President, V.M. Ioachim, N. Arghir, P. Draganescu-Brateş, G. Leonte, T.A. Teodoru and D. Constantinescu - members. At that time, what we now call branches were called sections, and Section Ilfov included Bucharest, too.

On November 6th 1921 was held the first Supreme Council of the Body. There were present G. Eremia - director of the National Bank, S. Cihoski - Rector of Academy of High Commercial Studies from Bucharest, E. Ionescu - Vice President of the Chamber of Commerce, N. Butculescu - Chairman of the Higher Schools of Commerce Alumni Corps, E. Paşcanu - director of School of Commerce C.D. Staicovici - Ilfov Section President Corps of Chartered Accountants and Expert Accountats, D. Contantinescu, P. and G. Draganescu-Brateş Leonte - as delegates of this body. They all voted the election of the first Permnent Office of the High Council.

First Permanent Office of the High Council in 1921:

- Gregore Trancu-Iasi - Honorary President

- Nicolae Butculescu - President, the title of Dean of the Corps

- Gheorghe Leonte, senior official in the BNR - general secretary

- Basil M. Joachim, vice president of the Stock Exchange Ploiesti - director

- Peter Draganescu-Brateo, senior official in the BNR, the delegate Bucovina - member of the Permanent Delegation

- Dem Constantinescu - member of the Permanent Delegation

In the autumn, on $1^{\text {st }}$ September, a new session of the Superior Council was held and there were made some changes in the composition of the Permanent Bureau. Thus, instead of D. Constantinescu are elected as members of the Permanent Delegation, N. Arghir and I.C. Negrescu, the rest remained unchanged Bureau.

The elections for both councils, territorial divisions and the Superior Council, took place in the general meetings held every two years - the years with pare numbers for councils sections and the unpair numberd years for the Superior Council. 
In 1923, the new elections didn't bring any changes for the Permanent Bureau membership, with one exception - Mr. Peter Draganescu-Brateş was elected general secretary in place of George Leonte.

For 10 years, this component of the Permanent Bureau has not changed, its members being re-elected each time in the elections of 1925, 1927, 1929 and 1931.

Only the 1933 elections there was a slight change in the composition of the Permanent Bureau, in fact complement, by creating a new functionality - the Dean, who was Professor Spiridon Iacobescu, from the Academy of High Commercial and Industrial Studies from Bucharest.

- Grigore Trancu-Iaşi - Honorary President

- Nicolae Butculescu - president, with the title of dean of the Body

- Prof .Univ. Spiridon Iacobescu, - dean

- Petru Drăgănescu-Brateş - general secretary

- Vasile M. Ioachim - director

In this composition the Bureau was functioning until 1939, being reelected in 1935, and in 1937.

During this period, the number of the sections created and the number of members increased steadil. Annually, the Sperior Council was making a statement of the number and structure of its members in sections. Thus, in 1926, the Body had constituted 56 sections and was composed of 6565 specialists, including 1932 experts, 4076 charted accountants and 557 trainee accountants. Four years later, in 1930, we are witnessing a spectacular growth, with 62 county sections and 11.130 members, of which 2302 experts, 7468 charted accountants and 1360 trainee accountants. The peak in the organization and the number of members was recorded between 1938-1939. Then the Body had 70 sections and the number reached nearly 15,000 members.

On $5^{\text {th }}$ November 1939, Nicolae Butculescu resigns as Dean of the Corps, a position which he held for 18 years. The proposal, in his place was Professor Spiridon Iacobescu, which becomes the second dean of the Body. Nicolae Butculescu was elected dean of honor of the Body.

The new Permanent Bureau of the Corps, which will run until March 1941, had the following composition:

- Nicolae Butculescu - honorary president

- Spiridon Iacobescu - dean

- Petru Drăgănescu-Brateş - general secretary

- Vasile M. Ioachim - director

The Second World War had negative consequences for our country and for accounting body, but also for the accounting profession in general was the beginning of decline.

With a military regime, the restriction of civil rights and mass concentrations was almost impossible to hold the elections so that the Council departments and the Superior Council of the Body were replaced by interim management committee, appointed by ministerial decision.

Because the mandates of the sections of the Body Councils expired on December 31, 1939, and most members of the Body were concentrated and could not participate in elections, the Ministry of Labor, signed by Mihai Ralea, issued a decision on 16 January 1940, which called interim management committee of the Body section.

But appointments through ministerial decisions do not stop just at the territorial divisions, but also reflect on the Superior Council of the Body leadership. Thus, the decision of the Ministry of Labour, on 25 March 1941, in the presence of Voiculescu general, secretary of state, has held the interim appointment of a committee of the Superior Council of the body, the Bureau shall elect the following members:

- Professor Spiridon Iacobescu. - dean

- Professor Ion Evian - pro/dean

- Ion Popescu-Severin - general secretary 
We can just notice the fact that at the leadership of the Body were two of the most important professors at those time, professor Evian,, from the Academy from Cluj, and professor Iacobescu, from the Academy from Bucharest, this shows the strong connection between the development of the profession and the higher education.

On 20 March 1941 at the initiative of Minister N. Dragomir, constitute a special Body of experts with the application of control policy and guidance prices. In this body were appointed 30 experts of the most distinguished personalities of the Body.

Because of the loss of territories, the members of the body decreased significantly since 1939, the assets Body divisions in the occupied territories were seized, and the situation was more than uncertain. In occupied territories, the situation was dramatic, many of the Body sections not knowing anything about wath was happening. Periodically, the leadership of the Supreme Council gave announcements, especially through the Body magazine.

Only after four months since when was installed the interim committee of the Superior Council, on 19 July 1941, throught the decision no. 59316 the Ministry of Labour a new interim commission was appointed, which had the following members of the Permanent Bureau:

- Gheorghe Badea, director general of Alcohol Direction - dean

- Professor Cezar Miron - pro/dean

- Nicolae Tripcovici - general secretary

- Constantin Pristăvescu - director

In 1941 the interim commissions of Ilfov section resigned, there was a need of electing a new interim comision:

- Professor Ion Evian - dean

- Ion Popescu-Severin - general secretary

- Constantin Pristăvescu - director

After the establishment of the communist regime the free enterprise is replaced by driven economy, which reflects, inevitably, in the accounting profession, a liberal profession par excellence.

In 1947 was set up the Permanent Council of accounting legislation and the Ministry of Finance will coordinate the entire methodology of legislation.

In 1948 occurs the nationalization of the main means of production, so that centralized economic controls all become works one hundred percent. Under these conditions, the existence of a Body of independent accountants became almost impossible.

Indeed, over just three years after the Decision of the Council of Ministers (headed by Dr. Petru Groza) no. 201 of March 8, 1951, the Grand National Assembly (under the chairmanship of CI Parhon) issued Decree no. 40 of March 10, 1951, which abolishes the Body of Chartered Accountants and Chartered Accountants.

\section{Conclusions}

The development of the commerce was the principal cause of the increasing importance of the accounting. The business needed people that knew bookkeeping elements, this is why it appeared the schools of commerce were accounting elements were taught.

These schools of commerce were not seen as the best schools from the country but them delivered the accountants needed for the development of economy. The schools of commerce represented the first forms of education in the economic field and these developed from elementary education to high school.

The evolution and the history of the higher education in the accounting field in Romania and the accounting profession are strong related. First of all a group of intellectuals, the alumni from the schools of commerce stated for the set up of the Academy from Bucharest, the first arrangement of higher education in the economic field from Romania. After a short period of time it was established the Academy from Cluj-Napoca, also by this elite group. 
The Circle of the Alumni was fighting for the regulation of the accounting profession, and the first recognise organisation of the accountants it was set up in the same year with the Academy from Cluj-Napoca. If we looks at the composition of the leadership of the Body of accountants we can see that there were the professors from Bucharest, Cluj-Napoca and Iasi.

Te communist period is ,the black" period when the accounting profession and the Academies are abolished. The socio-economic and political context didn't need any more accounting education and accounting profession, or at least this is what they thought.

\section{References}

1. Abbott, A., 1988. The system of professions: An essay on the division of expert labor, University of Chicago Press., xvi, 435 pp, Chicago

2. Albu, C. N, Albu, N., Alexander, D., 2010. Accounting change in Romania - a historical analysis, EUFIN 2010

3. Anderson-Goughin, F., Edwards, J.R., Walker, S.P., 2009. The routledge companion to accounting history, Routledge Press, London

4. Calu, D., A., 2005. Istorie şi dezvoltare privind contabilitatea din România [History and development regarding the accounting in Romania], Ed. Economică, Bucureşti

5. Carnegie, G.D. and Napier, C.J., 1996. Critical and Interpretive Histories: Insights into Accounting's Present and Future Through its Past, Accounting, Auditing \& Accountability Journal, Vol.9, No.3:7-39.

6. Demetrescu, C. G., 1972. Istoria contabilității [The history of accounting], Ed. Stiintifica, Bucuresti

7. Dyball, M.C., Poullaos, C., Chua, W.F., 2007. Accounting and empire: Professionalizationas-resistance: The case of Philippines, Critical Perspectives on Accounting, Volume 18, Issue 4, May, Pages 415-449

8. Ildieru, N.E., 1907. Istoria învățământului nostru comercial [The history of our commercial education], Bucharest

9. Ionaşcu, I., 1997. Epistemologia contabilităţi, Ed. Economică, Bucureşti

10. Parker, R. , 1993. The Scope of Accounting History: A Note, Vol. 29, Abacus

11. Pop, D., 2005. Şcoala economică clujeană interbelică[ The Cluj Economic School in the inter-war period], Ed. Efes, Cluj-Napoca

12. Popescu, Gh.(coord.), 2010. Învăţământul Economic Superior din Ardeal 920-2010[The Higher education system in Transylvania between 920-2010], Ed. Ardealul, Cluj-Napoca

13. Tiron Tudor, A., Dumitru, M., 2010. Options for a Modern Accounting System in $19^{\text {th }}$ century Transylvania, Transylvanian Review, Vol. XIX, No. 1,

14. Vorovenci, I. 2010. Istoria Academiei de Inalte Studii Comerciale si Industriale 1913-1947 [The history of the Academy of High Commercial and Industrial Studies 1913-1947], Ed. ASE, Bucharest

15. West, B.P, 1996. The professionalisation of accounting. A review of recent historical research and its implications, Accounting History, May, vol. 1, no. 1 p.77-102

16. Woolf, A. H., 1986. A short history of accountants and accountancy, Garland Pub., New York

17. Zelinschi D., 2009. Legitimacy, expertise and closure in the Romanian accountants' professional project, 1900-16, Accounting History Review, Vol. 14, No. 4:381-403

18. http://www.ceccar.ro/?P=A1256 